\title{
ТЕХНОЛОГІЯ ПІДГОТОВКИ МАЙБУТНЬОГО ВЧИТЕЛЯ ІНФОРМАТИКИ ДО РОБОТИ У КЛАСАХ ФІЗИКО-МАТЕМАТИЧНОГО ПРОФІЛЮ
}

\begin{abstract}
Федорчук А. Л. Технологія підготовки майбутнього вчителя інформатики до роботи у класах фізико-математичного профілю.

Статтю присвячено особливостям підготовки майбутнього вчителя інформатики до роботи у профільних класах. Подано технологію підготовки майбутнього професіонала щуодо роботи у класах фізико-математичного профілю.

Ключові слова: підготовка майбутнього вчителя, готовність учителя інформатики, технологія підготовки вчителя.

Федорчук А.Л. Технология подготовки будущего учителя информатики к работе в классах физико-математического профиля.

Статья посвящена особенностям подготовки будущего учителя информатики к работе в профильныл классах. Представлена технология подготовки будущего профессионала по работе в классах физико-математического профиля.

Ключевые слова: подготовка учителя, готовность учителя информатики, технологии подготовки учителя.

Fedorchuk A.L. Technology Training of Teachers to Work in Science Classes of Physical and Mathematical Profile.

The article deals with the peculiarities of preparation of future teachers science to work in specialized classes. Technology of preparing future professionals to work in school physics and mathematics account.

Key words: training future teachers, teacher preparedness science, technology teacher training.
\end{abstract}

Актуальність дослідження. Інформація - стратегічний ресурс XXI століття. Україна, інтегруючись у світовий інформаційний простір, як молода суверенна держава, зацікавлена у підвищенні рівня інформаційної культури своїх громадян. У цій справі важливого значення набувають професійна підготовка та професійна діяльність учителя інформатики, який $\epsilon$ не тільки запорукою належного рівня інформаційної культури учнівської молоді, а й гарантом впровадження сучасних інформаційних технологій у всі сфери діяльності суспільства.

Аналіз останніх досліджень та публікацій. Проблемі професійної підготовки вчителя завжди приділялася належна увага як на державному рівні, так і на науково-методичному. Так, серед сучасних наукових праць щодо ефективного навчання інформатики переважають дослідження, які висвітлюють: організаційно-педагогічні аспекти цієї проблеми у середніх навчальних закладах (Н. Апатова, Л. Білоусова, А. Верлань, М. Жалдак, Б. Житомирський, М. Лапчик, О. Меняйленко, Н. Морзе, К. Пахотін, Ю. Рамський, В. Руденко, О. Спірін та інші); видозміни в діяльності та особливості спілкування «педагог - учень» із використанням інформаційних технологій (А. Брушлінський, Т. Габій, А. Матюшкін, С. Машбиць, О. Тихомиров). 
Мета статті. Аналіз наукових джерел, зокрема й педагогічних досліджень, надають нам можливість стверджувати, що недостатньо теоретично і методично вивченим залишається такий аспект, як підготовка вчителя інформатики до роботи в класах фізико-математичного профілю, що й стало метою нашої статті.

Виклад основного матеріалу. Результати нашого дослідження дозволили стверджувати, що в сучасних умовах профільного навчання старшокласників потребує вдосконалення та розробки нова технологія підготовка майбутнього вчителя інформатики. 3 цією метою нами було розроблено технологію підготовки майбутніх учителів інформатики до роботи в класах фізико-математичного профілю.

Технологія підготовки вчителя інформатики щодо роботи в профільних класах дала можливість висунути ряд завдань формувального етапу дослідження: переорієнтація курсу методики викладання інформатики на формування готовності вчителя інформатики до роботи в класах фізикоматематичного профілю; формування у майбутніх фахівців мотивації постійного професійного самовдосконалення та саморозвитку, самоаналізу та самоконтролю; розвиток у майбутніх учителів інформатики низки знань 3 методики викладання інформатики в профільних класах та психологопедагогічних особливостей вчителя як предметника; виховання у студенів уявлення про власну суспільну значимість обраної професії в умовах профільного навчання; на основі результатів формувального експерименту внести корективи до розробленої технології підготовки майбутнього вчителя інформатики до роботи в класах фізико-математичного профілю.

Необхідно зазначити, що розвиток достатнього рівня готовності студентів до роботи в класах фізико-математичного профілю стане можливим, якщо у процесі вивчення курсу «Шкільний курс інформатики та методика навчання» студенти ознайомлюватимуться 3 концепцією, основними положеннями та засадами профільного навчання, будуть підвищувати рівень самовдосконалення завдяки стимулюванню до активної творчої діяльності у профільних класах, зміцнювати навики та вміння самоаналізу та саморегуляції під час проведення практичних та лабораторних занять, педагогічної практики та індивідуальної роботи.

Під час розроблення експериментальної технології ми керувались такими принципами: цілісності, гуманізації, фундаменталізації, індивідуалізації та диференціації як основних засад профільного навчання, модульності (весь курс був поділений на функціональні модулі), що відповідали цілям та змісту підготовки майбутнього вчителя інформатики.

Урахувавши наукові пошуки дослідників (О. Антонова, О. Дубасенюк, В. Єремеєва, М. Левківський, Н. Сидорчук та інші) [3], оригінальну таксономію освітніх цілей Б. Блума [2], ми співвіднесли категорії з рівнями сформованості: категорія знання відповідає репродуктивному рівню, розуміння - адаптивному, застосування - конструктивному, аналіз творчому, синтез - дослідницькому, оцінювання - оцінно-узагальнюючому. 
Нижче подано таксономію навчальних цілей підготовки майбутнього вчителя інформатики до роботи в класах фізико-математичного профілю (подано категорію цілей та відповідно до неї змістову інтерпретацію категорій навчальних цілей):

1. Репродуктивний рівень (знання). Відтворювати основні поняття курсу, висвітлювати конкретні факти, методи та процедури, основні поняття, правила та принципи профільного навчання. Знати історичні та соціальні передумови становлення та розвитку профільного навчання; теоретичні й концептуальні основи навчального процесу в умовах профільного навчання; зарубіжний досвід застосування умов профільного навчання.

2. Адаптивний рівень (уміння). Розкривати взаємоозумовленість впливу різних чинників на навчально-виховний процес сьогодення, передумови активного впровадження профільного навчання; особливості та етапи впровадження профільного навчання в інформатиці. Усвідомлювати сутність основних понять профільного навчання, осмислювати сучасні тенденції розвитку профільного навчання в сучасній школі. Розуміти та пояснювати роль технології профільного навчання в підготовці компетентного випускника ВНЗ.

3. Конструктивний (застосування). Демонструвати на конкретних прикладах впровадження тих чи тих тем фізико-математичного спрямування в інформатиці. Розробляти навчальні плани, які передбачають роботи в профільних класах. Моделювати ситуації взаємодії вчитель-ученькомп'ютер. Конструювати моделі впровадження інтегрованих тем на фізикоматематичну тематику на уроці інформатики.

4. Творчий рівень (аналіз). Аналізувати сучасні педагогічні концепції, теорії профільного навчання; основні проблеми та перепони на шляху впровадження профільного навчання; власну діяльність та діяльність студентів. Пояснювати специфіку та необхідність впровадження фізикоматематичної тематики в інформатиці в умовах профільного навчання. Обгрунтувати ефективність застосування певної технології у шкільному курсі інформатики. Застосовувати свої знання в нестандартних умовах. Розпізнавати та виправляти помилки та недоліки у власній діяльності.

5. Дослідницький рівень (синтез). Виокремлювати серед передового педагогічного досвіду напрацювання вчителів інформатики, які ефективно впроваджують профільне навчання. Готувати творчі завдання, повідомлення, розробку тестових завдань, розробляти план діяльності гуртка 3 інформатики. Узагальнювати результати своєї роботи. Використовувати знання з педагогіки, психології, фахових дисциплін.

6. Узагальнювальний рівень (оцінка). Оцінювати значення впровадження профільного навчання у підготовці сучасного компетентного вчителя інформатики та у формуванні особистості випускника загальноосвітньої школи. Оцінювати сучасні навчальні програми, підручники, посібники 3 інформатики з огляду на можливість адаптування їх до профільного навчання в фізико-математичних класах у цілісній системі курсу. Висловлювати власну позицію. Оцінювати власну діяльність, рівень розробок планів, конспектів, контрольних завдань, проектів майбутніми вчителями. 
На формувальному етапі експерименту змістовий блок містив такі дисципліни: «Педагогіка», «Психологія», фахові дисципліни, «Шкільний курс інформатики та методика навчання», власне на якому i передбачено впровадження нашої технології у навчально-виховний процес. Курс проводився зі студентами, поділеними на підгрупи по 10-15 осіб у комп'ютерних класах. Це надало змогу створити сприятливу емоційну атмосферу на заняттях, довірливі стосунки, яким притаманне взаєморозуміння, співпереживання, результатом стане виступати співробітництво, співтворчість, які забезпечують ефективність навчальної діяльності.

Для ефективної реалізації експериментальної технології підготовки студентів курс «Шкільний курс інформатики та методика навчання» був модифікованим та знайшов своє відображення у методичному посібнику «Підготовка майбутнього вчителя інформатики до роботи в класах фізикоматематичного профілю в процесі вивчення методики навчання інформатики» [4]. Практична підготовка майбутнього вчителя інформатики здійснюється під час проведення лекційних, семінарсько-практичних, лабораторних робіт та педагогічної практики.

Слід зазначити, що метою розроблення нашої технології підготовки студентів $\epsilon$ створення умов для реалізації потреб та інтересів, професійного становлення майбутнього фахівця, творчої самореалізації, вибору власної траєкторії розвитку майбутнього професіонала.

В основу змісту курсу «Підготовка майбутнього вчителя інформатики до роботи в класах фізико-математичного профілю в процесі вивчення методики навчання інформатики» покладено такі нормативні документи: Закон України «Про освіту», Закон України «Про вищу освіту», Державна програма «Вчитель», Національна доктрина розвитку освіти, Державний стандарт базової і повної загальної середньої освіти, Концепція профільного навчання в старшій школі.

Модифікований курс поділено на 6 модулів, кожен 3 яких містив змістову та практичну частини. Сучасні науковці вважають, що важливою технологією підготовки майбутнього вчителя інформатики до роботи в профільних класах $є$ технологія модульного навчання. Вона передбачає, в порівнянні з традиційною лекційно-семінарською системою, що професійна діяльність викладача, як і навчальна діяльність студента, набувають нового характеру: центральною фігурою навчального процесу реально стає студент.

Нова система організації навчально-пізнавальної діяльності принципово змінює психологію студента: нові обставини переконують студента в тому, що він має працювати самостійно, ініціативно, систематично.

Змістова частина представлена у вигляді певної послідовності тем, за якими відбувався лекційний розгляд теоретичного матеріалу. Лекційний курс орієнтований на проблемний діалог, евристичну бесіду, де відбувалося обговорення базових положень методики викладання інформатики в умовах профільного навчання.

Широкого застосування під час викладання нового матеріалу набули 
різні типи лекцій, а саме: вступна лекція (застосовувалася на початку вивчення курсу), інформаційна, проблемна, дискусійна, лекція-конференція, лекція-консультація, лекція-презентація. Останній тип лекції дав можливість унаочнено представити матеріал на слайдах у вигляді коротких тезисних фраз, таблиць, схем, діаграм та графіків, що значно сприяло покращенню подання структурно-логічних зв'язків теми та запам'ятовування матеріалу.

Практична частина навчальних занять містила тематику заняття, його мету, теоретичні відомості, подані у вигляді схем, таблиць, списків, організаційних діаграм; власне план заняття; список рекомендованої літератури для підготовки до заняття, а також запитання для контролю та самоконтролю знань студентів.

На етапі узагальнення та систематизації знань передбачалася індивідуально-самостійна робота з опрацювання рекомендованих першоджерел, підготовка повідомлень (рефератів), робота в Інтернеті тощо.

Методичні рекомендації дають студентам можливість ознайомитися 3 планом роботи на наступне заняття заздалегідь, спланувати самостійну діяльність, порівняти власні досягнення 3 вимогами до знань та вмінь. Студенти отримують індивідуальні завдання, такі як: підготувати інформаційне повідомлення, написати творчий проект або реферат, розробити дидактичний матеріал, скласти конспект уроку, розробити підсумкову роботу, скласти тематичне та поурочне планування.

Пропонуються такі теми рефератів, як: тенденції розвитку шкільного курсу інформатики в старшій школі в умовах профільного навчання; вимоги до вчителя профільного курсу інформатики; порівняльний аналіз підручників для профільного навчання інформатики; модульні технології навчання в профільному курсі інформатики; виявлення та підтримка найбільш обдарованих, талановитих дітей під час навчання інформатики на старшому ступені школи; можливі індивідуальні освітні траєкторії для учнів фізико-математичного профілю під час навчання інформатики; урахування професійних переваг в профільному курсі інформатики; індивідуалізоване навчання у профільному курсі інформатики; парне та групове навчання інформатики на старшому ступені школи в умовах профільного навчання; метод проектів у профільних і елективних курсах з інформатики; зарубіжний досвід профільного навчання інформатики; методи викладання в профільному й елективному курсах 3 інформатики; методика вивчення розділу за вибором в курсі інформатики одного з профілів тощо.

Формами організації діяльності під час практичної підготовки є:

1. Педагогічний тренінг, що передбачає відпрацювання вмінь і навичок застосування елементів різних навчальних технологій.

2. Ділова професійно-орієнтована гра, спрямована на проектування та мікровикладання фрагментів уроків інформатики на основі використання сучасних навчальних технологій в умовах профільного навчання. 
3. «Круглий стіл», який використовується для прийняття кількох рішень 3 конкретної проблеми; мозковий штурм, що спонукає студентів розвивати свою уяву і творчість, уможливлює вільне висловлювання ними власних думок.

4. Робота в малих групах, яка організується для розв'язання складних проблем, що потребують колективного обговорення, та використовується задля формування вмінь і навичок діалогічного спілкування, співробітництва, співтворчості.

5. Створення навчально-методичних матеріалів (самостійне та колективне), яке передбачає обговорення 3 колегами розроблених навчально-методичних матеріалів, тематичне та поурочне планування, підсумкові роботи для здійснення контролю, оцінювання і самооцінювання навчальної діяльності студентів щодо створених ними окремих складників загалом тощо.

6. Обговорення та аналіз створених елементів портфоліо майбутнього викладача, що сприяють розвитку навичок професійно-педагогічного діагностування та самодіагностування.

Залучаючи студентів до групової роботи, де вони є суб'єктами спільної навчальної діяльності, ми змінюємо їх мотиваційну сферу в напрямку навчання. Така робота дає позитивні результати та робить очевидним зусилля кожного студента. Групова робота $\epsilon$ особливо цінною під час проблемного навчання. Завдяки проведенню ділових ігор, обговоренню за «круглим столом» виникають суперечки, які викликають потребу в опануванні знань та вмінь для розв'язання проблемних ситуацій. Завдяки проблемному навчанню підсилюється ступінь досягнення цілей навчання, підвищується якість i міцність отриманих знань та умінь, що надає навчальному процесу більшої емоційності та жвавості, посилює пізнавальну активність студентів, уповільнює зниження показників функціонального та психологічного стану, поліпшує самопочуття та настрій студентів, сприяє настанові на вдосконалення та бажання вчитися, має ефект емоційного підкріплення, яке сприяє становленню психічних новоутворень, що лежать в основі процесу набуття нових знань, умінь, навичок [1, с. 130].

Важливим $\epsilon$ те, що задля формування у студентів професійної компетентності щодо роботи в класах фізико-математичного профілю ми, окрім занять, які стосуються загального курсу методики навчання інформатики, включили заняття, які забезпечують ширше ознайомлення 3 питаннями профільного навчання. Зокрема, при вивченні модуля №6 «Профільне навчання» тема «Профільні курси як засіб диференціації навчання інформатики у старшій школі» надало можливість студентам краще ознайомитись 3 навчальними програмами та підручниками для профільного навчання, зорієнтованих на поглиблене вивчення інформатики, з'ясувати особливості та зміст викладання таких курсів. Інструкція до лабораторної роботи містила в собі теоретичні відомості у вигляді таблиць, списків та організаційних діаграм, що надало змогу студентам більш докладно ознайомитися 3 новим матеріалом під час підготовки до заняття, скоригували напрям їх роботи.

Система комплексного оцінювання готовності майбутніх учителів 
інформатики до роботи в класах фізико-математичного профілю включала:

1. Вхідний контроль. Діагностувальне анкетування задля визначення теоретичного рівня та запитів студентів. Фаховий зріз знань: тестування; контролі роботи, співбесіди, анкетування.

2. Поточний контроль під час курсу. Експрес-контроль якості засвоєння основних розділів навчально-тематичного плану: тестування, короткі письмові роботи тощо. Контроль за результатами вхідного контролю: виконання індивідуального завдання, курсових робіт, самоосвітня робота, виконання індивідуального плану.

3. Вихідний контроль. Анкетування задля самооцінки рівня сформованості готовності педагога, захист курсових робіт, захист творчих робіт, залік, анкетування задля оцінки ефективності курсу.

4. Рейтингова оцінка експертною фаховою комісією відповідності рівня теоретичних знань майбутнього вчителя вимогам кваліфікаційних характеристик.

5. Післякурсовий контроль. Вивчення результативності роботи вчителя в школі, анкетування адміністрацією школи, методистами щодо професіоналізму педагога, анкетування учнів для виявлення професіоналізму дій вчителя, контрольні зрізи знань учнів.

Напрями роботи зі студентами: консультації щодо підготовки курсових робіт, ліквідації прогалин у фахових знаннях, окремих питань теорії та методики навчання; індивідуальна робота щодо виконання курсових робіт; рекомендації щодо опрацювання нової психолого-педагогічної літератури; надання допомоги в підготовці до практики; організація факультативних занять, спецкурсів за проблемами, визначеними вхідним діагностуванням; надання допомоги у доборі належної літератури у процесі підготовки до заняття.

Висновки та перспективи подальших розвідок. Отже, така організація навчально-виховної діяльності виховує у майбутнього вчителя інформатики певні особистісно-професійні якості: організованість, послідовність, комунікабельність, толерантність, прагнення до постійного професійного саморозвитку тощо, необхідні йому для подальшого розвитку професійної компетентності щодо вдосконалення роботи з учнями у профільних класах.

\section{Література}

1. Педагогічні технології у неперервній професійній освіті: [монографія] / С. О. Сисоєва, А. М. Алексюк, П. М. Воловик, О. І. Кульчицька, Л. С. Сігаєва, Я. В. Цехмістер та ін.; за ред. С. О. Сисоєвої - К. : ВІПОЛ, $2001-502$ с.

2. Таксономия Блума: [електронний ресурс]. - Режим доступу: http://ru.wikipedia.org/wiki/Таксономія_Блума

3. Технології професійно-педагогічної підготовки майбутніх учителів: [навч. посіб.]; у 2 ч. / за заг. ред. д-ра пед. наук О. А. Дубасенюк. - Житомир : ЖДПУ, 2001. - Ч. 1: Технології загальнопедагогічної підготовки майбутніх учителів. -267 с.

4. Федорчук А. Л. Підготовка майбутнього вчителя інформатики до роботи в класах фізико-математичного профілю в процесі вивчення методики навчання інформатики : [метод. посіб. для студ. вищих навч. закл.] / А. Л. Федорчук. - Житомир : Вид-во ЖДУ ім. І. Франка, 2012. - 168 с.

Стаття надійшла до редакції 27.05.2012 p. 